\title{
Ajman an environmentally friendly city with its quality of life: review of sustainability challenges and achievements by Ajman Municipality and Planning Department
}

\author{
Khaled Mueen Alhosani ${ }^{1,{ }^{*}}$, Yaser Omar Kaied ${ }^{2}$, and Abdul Salam Kareem Darwish ${ }^{3}$ \\ ${ }^{1}$ Public Health and Environment Sector, Ajman Municipality and Planning Department, UAE \\ 2 Environmental Development Department, Ajman Municipality and Planning Department, UAE \\ 3 University of Bolton, UK
}

Received: 15 February 2021 / Received in final form: 21 March 2021 / Accepted: 22 March 2021

\begin{abstract}
The increasing debate on sustainable development has raised attention by many global sectors such as policymakers and developers for advanced sustainable cities and the corresponding sustainability impacts on urban transformation. UAE Government has initiated a task to focus on improving air quality, preserving water resources, increasing clean energy, implementing green growth plans, and further enhancing its citizens' quality of life. Ajman is the smallest Emirate and through the The Ajman Municipality and Planning Department has carried out in corporation with the other Governmental authorities started to initiate plans, policies, and initiatives for this purpose. The increase in population, society wellbeing, lifestyle and industrial revolution in the Emirate of Ajman - UAE, resulted in increased challengesinitiated for the Ajman Municipality and Planning Department (AMPD). These challenges align with national and international strategies and goals targeting the urgent environmental, social and economic issues. Therefore, Ajman Municipality has set up a prime aim to embed sustainability through every life aspect and consider sustainability an integral part of its vision and mission. Municipality sustainability performance was enhanced to incorporate sustainability into all activities to ensure wellbeing and happiness and transform the Emirate of Ajman into a sustainable city and its inhabitants blessed with a beautiful, comfortable life. This paper provides an overview of all the challenges and achievements of the Ajman Municipality and Planning Department (AMPD), highlighting the success factors to support initiatives that serve to advance the United Nations' sustainable development agenda. Lessons from the achievements are considered as guidelines for a framework model that can be used for future planning and development.
\end{abstract}

\section{Introduction}

The sustainable and smart city concept is getting much attention is one of the essential topics in today's public policy [1]. The idea of smart and sustainable cities emerged in the 1990s [2]. It started to be Governmental targets due to the lifestyle advancements,and the impacts of climate change on the economy and society. According to the 2008 report of the United Nations Population Fund, $70 \%$ of the world's population is expected to live in cities by 2050 [2]. More than 830 million people are still not living in proper houses and have been deplorable [3]. The increasing debateon sustainable development has raised attention by many global sectors such as policymakers and developers for advanced sustainable cities and the

\footnotetext{
* e-mail: Kalhossani@am.gov.ae
}

corresponding sustainability impacts on urban transformation [4,5]. There is a combined link for having sustainable cities with smart technologies, but smart technologies can be used without considering sustainability developments [6-8]. It is believed that $70 \%$ of primary domestic energy usage being committed to buildings leads to energy and environmental challenges [9]. Then the need for energy-efficient buildings is a prime aim. It is considered by [9], that in order to approach building energy sustainability, sustainable energy resources are essential to be considered. By 2050, nearly $70 \%$ of the global population will be living in cities, up from $50 \%$ today. Cities account for more than $70 \%$ of the worldwide carbon emissions. Smart, sustainable cities use information and communication technologies to (ICTs) improve urban services and quality of life. In some cities, ICTs are already enhancing energy efficiency, boosting traffic safety, or alerting police of crimes. The internet of things (IoT), 
Table 1. Ajman Municipality's strategic goals and the SDGs [12].

The municipality's strategic goals description
G1- Achieve integration between infrastructure
and residential elements Sustainable environment
while developing a modern in Ajman

G2- Qualify and protect the environment

G3- Manage the wastes efficiently and effectively empowerment

G4- Develop the Biological diversity Transparency and Integrity

G5- Ensure best use of resources Teamwork

E1- Develop human resources loyalty and Belonging
Relevant SDG

SDG 7: Affordable and clean energy

SDG 11: Sustainable cities and communities

SDG 2: Zero Hunger

SDG 13: Climate action

SDG 11: Sustainable cities and communities

SDG 12: Responsible consumption and production

SDG 11: Sustainable cities and communities

SDG 15: Life on land

SDG 16: Peace justice and strong institutions

SSDG 6: Clean Water and Sanitation

SDG 11: Sustainable cities and communities

SDG 5: Gender Equality and Women empowerment

Table 2. Ajman Municipality's most important material topics and the SDGs [12].

\begin{tabular}{lll}
\hline Aspect & Description & Relevant SDG \\
\hline & Infrastructuer and Roads & SDG 9: Industry innovation and infrastructure \\
& Reduce Traffic Congestion) & SDG 11: Sustainable cities and communities \\
& Waste Management Practices & SDG 13: Climate action \\
Most important & & SDG 15: Life on land \\
material topics & Community Healty and Well - Being & SDG 3: Good health and well- being \\
& (i.e food safety Air Quality) & SDG 13: Climate action \\
& Climate Change and Energy Efficiency & SDG 7: Affordable and clean energy \\
& & SDG 13: Climate action \\
\hline
\end{tabular}

Artificial Intelligence (AI), and smart grids are accelerating smart city development worldwide. Ensuring sustainable development while preserving the environment is a primary aim that the UAE Government has put forward in order to achieve a perfect balance between economic and social development [10].

For this purpose, the Government has initiated a task to focus on improving air quality, preserving water resources, increasing clean energy, implementing green growth plans, and seeking further to enhance its citizens' quality of life. Following this national trend, Ajman, the smallest Emirate of Ajman Emirate, is experiencing urbanisation as elsewhere in the developing world. Simultaneously, the Ajman Government ensures that settlement undergoes a structured process to eradicate urban poverty or informal housing in the city [11]. Ajman Municipality and Planning Department (AMPD) has initiated creativity practices that highlighted sustainability developments in all aspects within a short period. However, the AMPD is seeking a framework model that consists of successful parameters to enhance the Governmental program for achieving sustainable smart Ajman city. This paper reviews the challenges and achievements
AMPD has approached, exploring the parameters for success and guidance for further developments. Lessons from the achievements are considered as guidelines for a framework model that can be used for future planning and development. The paper is to set all successful factors that should be considered when planning, implementing and evaluating regulations and polices to achieve the UNSDGs.

\section{UN sustainable development goals and ajman municipality and planning department}

The United Nations Sustainable Development Goals (SDGs) aimed to restore the environment and assure the peace and prosperity for future generations. UAE is one of the nations that supported these goals. For this respect, Ajman has put forward plans to demonstrate its commitment towards sustainability by assessing the SDGs and mapped materials and strategies towards the SDGs [12]. Table 1 shows the Ajman Municipality's strategic goals and the SDGs. Also, Table 2 demonstrate the Ajman Municipality's Most Important Material Topics and the SDGs [12]. 


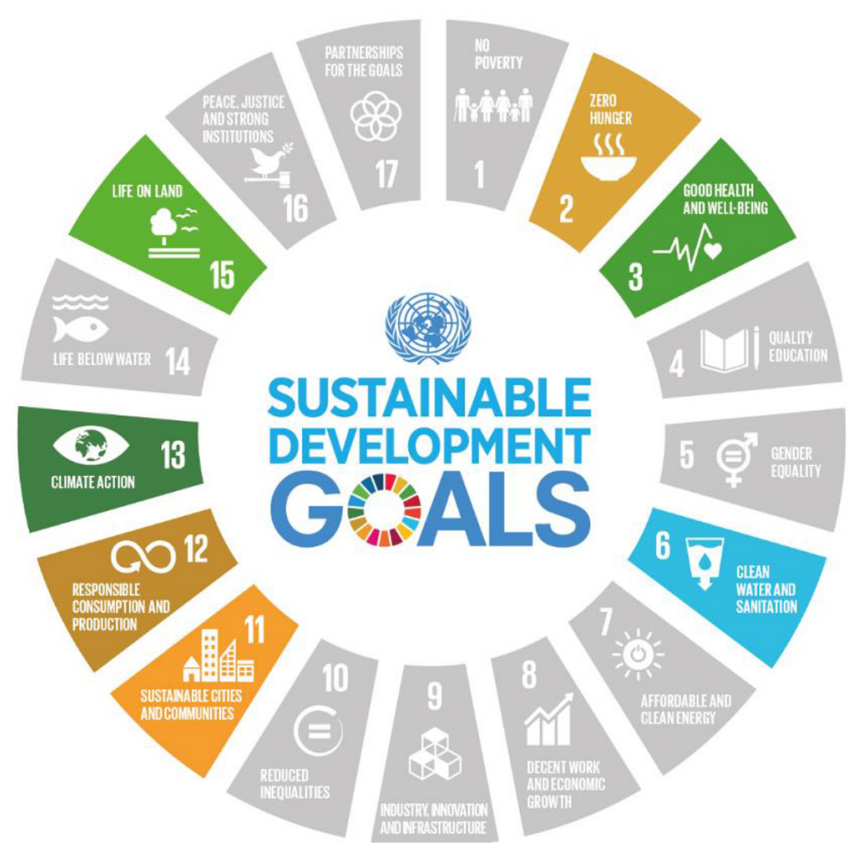

Fig. 1. SDGs related to air quality.

\subsection{SDGs related to air quality and implementation by AMPD}

SDGs related to air quality are well recognised by AMPD Figure 1. A broad perspective illustrates that air pollution is linked in principle to most SDGs, either in terms of causes (energy, industry, transport), the measurement of air pollution itself and impacts such as damage to ecosystems and health. Air pollution is mentioned explicitly under health (SDG 3: Good health and wellbeing), and cities (SGD 11: Sustainable cities and communities), but can be indirectly related to other goals such as water (SDG 6: Clean water and sanitation) in terms of improved water quality and restoration of water-related ecosystems, affordable and clean energy (SDG 7: Affordable and clean energy), industry (SDG 9: Industry, Innovation \&Infrastructure) in terms of environmentally sound technologies and industrial processes, cities (SGD 11: Cities) in terms of sustainable transport systems, climate (SDG 13: Climate action) in terms of integrating climate change measures into national policies, and land (SDG 15: Life on land) in terms of restoring sustainable use of ecosystems [13].

Ajman Municipality and Planning Department has had different practices to monitor the air quality. Plans are being implemented to maintain healthy air quality by raising awareness about the potential of good air quality for generations to come. Maintaining healthy air quality to ensure the sustainable development of the Emirate has been a strategic priority for the Municipality and Planning Department. In order to realise this ambition, the Municipality has installed Continuous Ambient Air Quality Monitoring Stations (CAAQMS) at various air quality sensitive locations in the Emirate of Ajman. These stationsmonitor parameters such as NOx, Sox, Ozone and Carbon Dioxide, and other components of Ajman's air. The plan for upcoming years is to add more monitoring stations in Ajman to cover more areas and ensure that the Emirate air quality is regulated and moving towards strengthening their air quality controls. In this respect, the AMPD commitment is to "Delivering the Required Solutions \& Consultancies, by the Right Way, on Time in a CostEffective Manner", as a means to partake in the municipality's drive to strengthen their environmental controls [12].

\section{Ajman municipality plans and achievements towards climate change and energy efficiency}

AMPD plans to contribute to the national efforts to reduce climate change factors' impact onlowering emissions through innovative measures and initiatives. Moreover, minimising waste with a target of zero landfills, using the latest technologies to ensure clean air and non-harmful to the environment complying with UAE federal and Ajman level legislations, regulations, and directives [12].

Sustainable energy provides affordable, accessible and reliable energy services that meet the economic, social and environmental needs within the overall developmental context of the society for which the services are intended while recognising equitable distribution in meeting those needs. The targets that have been forward are [14]:

- Low or zero emissions of carbon dioxide;

- No necessary ecological harmful impacts;

- Enhancing the security of energy transit;

- Reducing the cost of energy production;

- Improving the utilisation of green technologies.

One of the top priorities at AMPD was to maintain energy efficiency in all residential and industrial sectors. This has been planned to ensure all applications and performances are with the best practice standards. It reached a significant amount of energy saving by improving performance and high standard efficiency in all aspects. For this purpose, AMPD has followed many environmental initiatives as in Table 3, data adapted from [12].

\section{AMPD eco-friendly hybrid vehicles}

The environmental aspirations of Ajman's leadership and in order to harness alternative energy to help protect the environment, the Department of Agriculture and Public Parks at the public health and environment sector at AMPD has launched environmentally friendly hybrid vehicles, Figure 2, $[15,16]$ to guide, control and educate the visitors on Ajman's tourist sites and public facilities. This is to provide clean and renewable energy in public facilities for sustainable development.

\section{Sustainable waste management creative practices by AMPD}

In recent years, it is clear from all aspects that an increase in population growth, industrial and economic activities in the UAE resulted in the quantities of waste being generated have significantly increased. It has been observed that most 
Table 3. AMPD has followed many environmental initiatives.

\begin{tabular}{ll}
\hline Sector & Initiatives \\
\hline $\mathrm{CO}_{2}$ Emissions & Implementation of corrective measures to reduce environmental impacts and carbon \\
& emissions. \\
Recycling and & - Creation of a waste management inventory system. \\
Waste Management & - Supporting environmental sustainability through the recycling of all waste at the \\
& Municipality. \\
& - Contributing to the reduction of waste produced, which contributes to the support \\
& of environmental sustainability. \\
Electricity Saving & Replacing of fluorescent lamps with LED lamps, which resulted in savings of every \\
& year. \\
Hybrid Cars & Purchase of 15 hybrid Cars, which resulted in savings of 15 tons of CO2 emissions in \\
Renewable Energy & $\begin{array}{l}\text { Formulating a plan to install photovoltaic systems on roof tops of its facilities in order } \\
\text { to reduce electricity consumption. } \\
\text { Raising Awareness }\end{array}$ \\
& $\begin{array}{l}\text { The Municipality arranged an international conference for the environment and } \\
\text { sustainability every two years, to discuss relevant topics and material issues shared } \\
\text { between the Municipality and other concerned organisations. }\end{array}$ \\
\hline
\end{tabular}

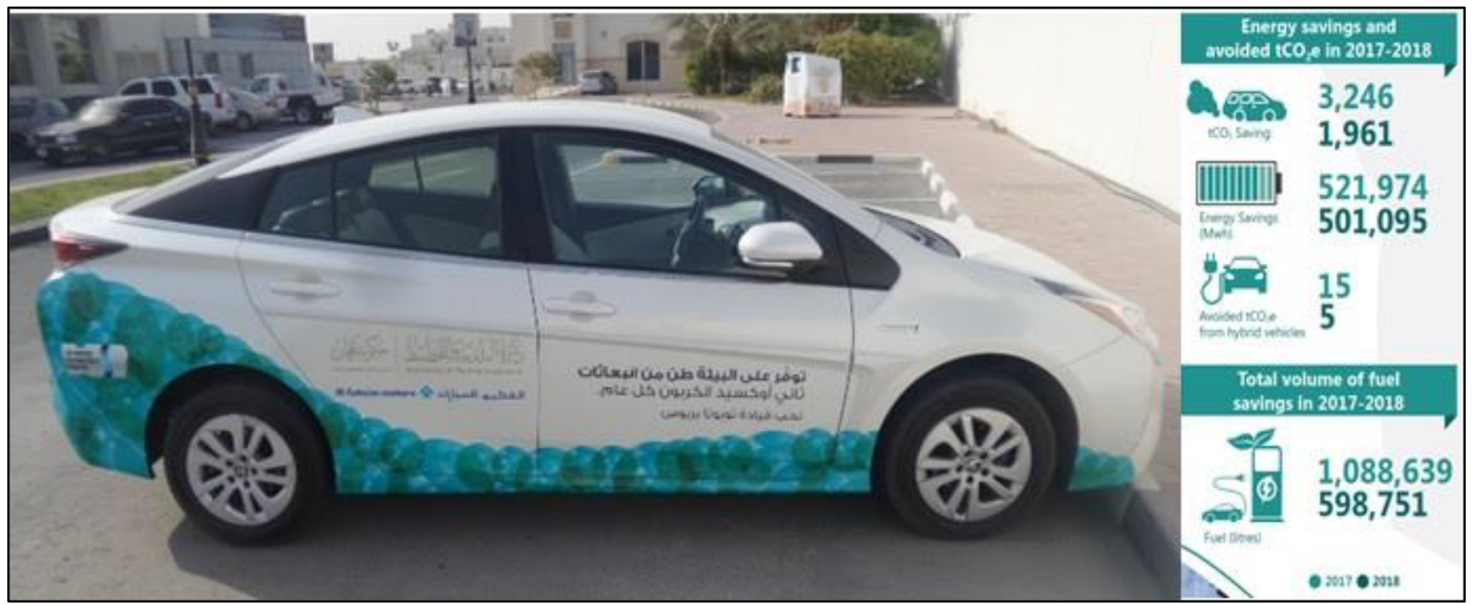

Fig. 2. One of the AMPD eco-friendly hybrid vehicles $[12,17]$.

of the trash generated ends up in municipal landfills or dumpsites, causing a continuous air pollution and greenhouse gas emissions. Therefore, the AMPD committed in line with UAE Vision 2021 aims to reduce the percentage of treated waste from total waste generated to $75 \%$ by 2021 [12]. In this respect, the target was to reduce the waste volumes by following many modern and practical measures such as implementing the 3Rs (Reduce,Reuse and Recycle), divert the waste from landfills. The authority has adopted two aspects for solutions which showed significant success in waste reduction. The first element is to create an incinerator used to treat non-chemical medical waste, generated from hospitals \& clinics leading to reduce the quantity of waste dumped in the landfill. The second aspect is the segregation of recyclable waste from non-recyclable waste transferred to the landfill and is dumped while the recyclable waste is sold. Liquid waste has also been managed successfully by the AMPD in cooperation with the private business sector.

\subsection{The waste management plan}

AMPD has initiated plans to achieve sustainable waste management that can provide [17]:

- Clear objectives for a Waste Management Plan in Ajman andmeasures to take to achieve these objectives;

- A planning process that is based on sound analysis of the mostreliable sources of data available;

- Evaluation of options for service development that seek to drivewaste management up the waste hierarchy;

- Clear timescales which set out a medium term and longtermstrategic vision in line with local and regional expectations; 


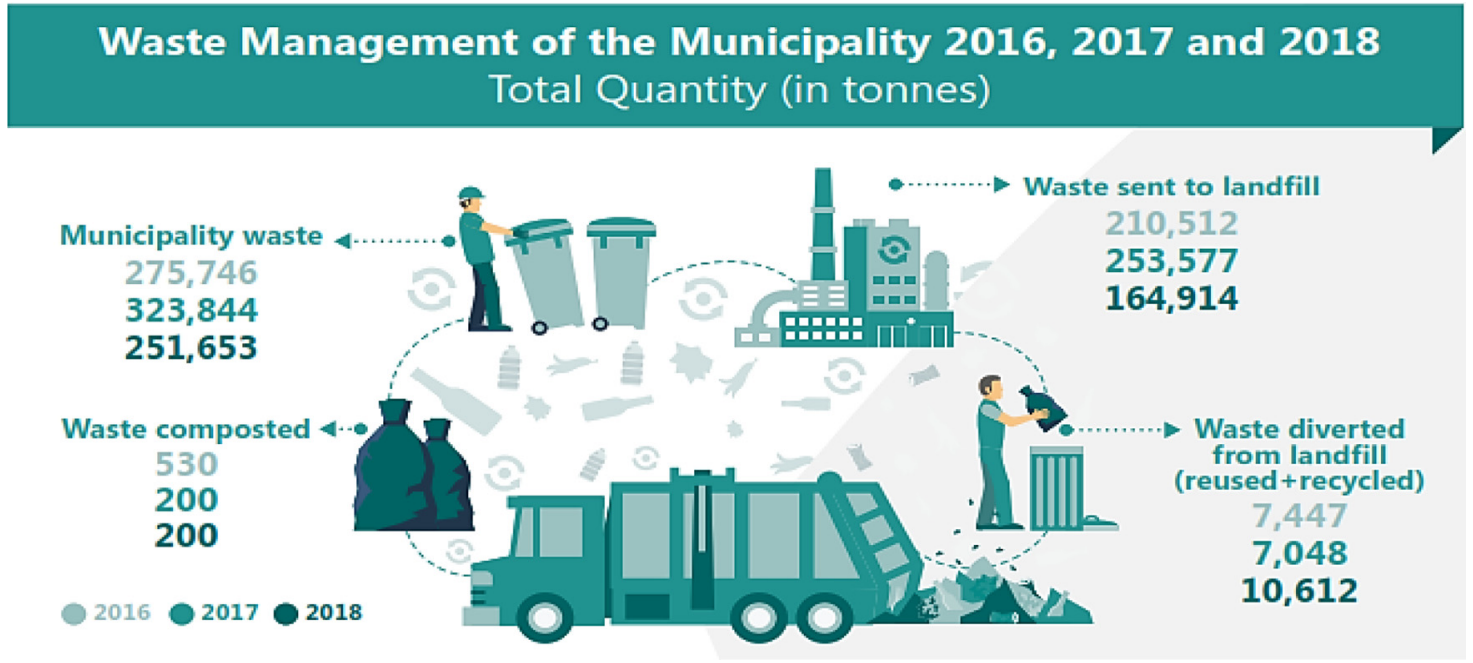

Fig. 3. Waste management of the municipality.

- A plan that aligns with existing federal and local wastemanagement frameworks seeks to encompassinternational best practice where applicable;

- A plan that recognises the Municipality's role to encouragebusinesses and communities to manage waste more sustainably.

The Waste Management Plan for Ajman is designed to make a real difference to the community through the way waste is managed in Ajman. As well as establishing a framework to guide Ajman's waste management practices over the next 15 years, the plan recognises the profound changes being seen in the region and should be refined over time.

The broader objectives of this plan will be to:

- Reduce the amount of unsorted and untreated waste going to landfill;

- Optimise current service provision;

- Consider treatment options for residual waste;

- Provide a basis for determining the new systems of infrastructure that may be needed.

Figure 3 [12], shows the waste management of the Municipality as a result of the sustainable plans and practices followed by AMPD.

\subsection{A day without plastic bags}

As a support for the sustainable waste management and in order to protect the environment A total of 25000 paper bags were distributed in ten shopping malls, and supermarkets in the Emirate as the Ajman Municipality and Planning Department launched its green environment campaign dubbed 'The Day Without Plastic Bags' since 2012 and still operating [12,18]. The campaign is recurrently carried out at ten shopping centres across the Emirate every year. This successfully reducedplastic bags usage by 5900000 units in 2017; the highest reduction rate has happened since this initiative started [12].

\section{The use of artificial intelligence in the environmental field in Ajman - mobile artificial intelligence laboratory}

The public health and environment sector at the Ajman Municipality and Planning Department works to benefit from the technological and technical development in the sector's work, especially environmental management, through creativity, innovation and the integration of the latest technologies through distinct and unprecedented projects. Two phases were planned for those projects of using artificial intelligence in the environmental field [19]. The idea of innovation that combines artificial intelligence and support for smart cities. The first phase was the introduction of an environmentally intelligent vehicle, Figure 4 . The mobile vehicle was designed to carry several advanced devices, including those used for the first time in the region and all supported by environmental artificial intelligence techniques. The vehicle provides accurate results and identifies pollution sources without human intervention, supporting the AMPD environmental inspection activities. Different facilities are provided to form a complete environmental Laboratory. For instance, one device system set up to measure gas emissions in real-time when the vehicle is at a standstill or moving. Coordinates are obtained at the time of recording at all positions and results are shown in the form of data, map and graphs indicating the type of gaseous pollutants at the measured areas.

Another device equipped with this vehicle is a measuring device for electromagnetic emissions resulting from armature towers and high-pressure electricity. It also works in a straightforward manner and analyses results directly without the need for immediate interruption or calibration. Among the modern technologies that have not been applied in the region so far is the smell recognition device using artificial intelligence. The administration continues to teach and train the device on various odour 


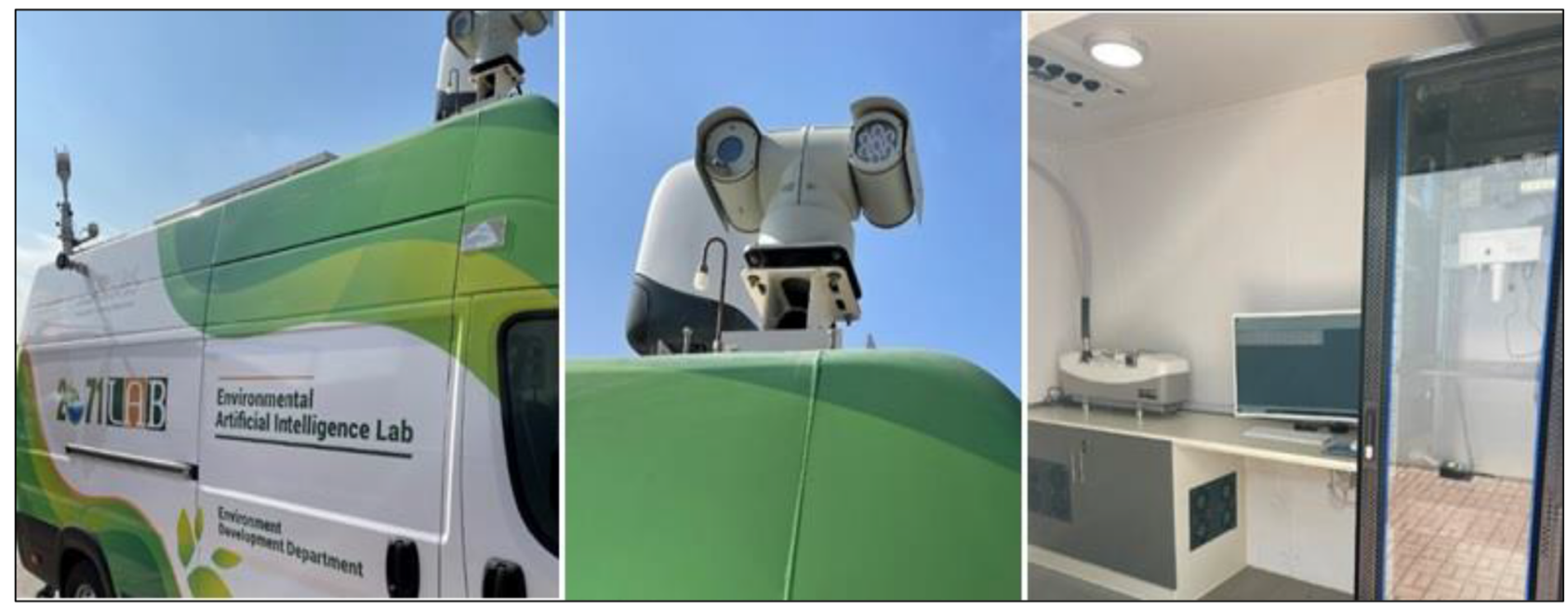

Fig. 4. Mobile artificial intelligence laboratory in Ajman [Authors official contact].

sources, including sewage plants, landfills, oil refining facilities, and oil processing. Utilities, plastics industry, bitumen, etc., and the device can determine the quality of odours. If the coordinates are determined and determined, the odours' source can be estimated directly by the device. The vehicle is provided with a tray of air samples taken to the laboratory for measurements or through an air quality monitoring station in the Al-Jarf area. The vehicle is also equipped with a dust measurement device loaded on the drone plus a 360-degree camera that moves in all directions. It is supported by artificial intelligence systems to detectpollution sources while among the distinctive additions is also a small drone for imaging and measuring suspended particles [20]. A unique facility is available in this laboratory, which is the environmental data management program. All environmental data sources are linked to the program within this facility, including air quality monitoring stations, groundwater quality measurement stations, sanitation data, and data collected from the smart vehicle. The program then analyses the data, issues the report and calculates indicators. The program is a first step towards introducingartificial environmental intelligence in most of the sector's activities to keep pace with development and raise environmental control and management efficiency.

\section{Environmentally friendly city towards sustainability}

In response to climate change, governments took responsibility for responding to the challenges of having the cities going green by providing resources, partnerships, and a platform to take climate action. As a starting step towards sustainability, the green cities were planned for environmentally friendly aspects supported by public awareness practices to approach eco-friendly cities and communities with satisfied lifestyle needs.Therefore, the targeted cities should be designed under consideration for social, economic, environmental effect and resilient habitat for current populations, without bargaining future generations' ability to experience the same [21]. Green, social, economic sustainability is the main pillars of environmentally friendly cities. Design opportunities focusing on these pillars will support the achievement of these cities. These designs must include minimising water, energy, and food inputs and significantly reducing waste and associated pollutions such as air pollution. In this respect, the following main features must be characterised in these cities [11]:

- Resources and services in the city are accessible to all supported by renewables;

- Public transport is seen as a viable alternative to environmentally friendly cars;

- Walking and cycling are safe and typical with minimum use of private cars;

- Areas of open space are safe, accessible, healthy, and enjoyable;

- Waste is seen as a resource and is recycled wherever possible with zero landfills;

- New green buildings are energy-efficient and affordable housing supported by smart technology.

Sustainable buildings are the prime factor for a sustainable city that provides the following benefits [22]:

- Lower Life Cycle Costs;

- Lower Insurance Fees;

- Higher Property Value;

- Higher Productivity;

- Improved Image;

- Reduced Risks;

- Healthier for Tenants and Visitors;

- Reduced Effects on Infrastructure;

- Better for the Environment and Local Economy.

Therefore, it is essential to carefully consider the certification level and the rating system when assessing how green or sustainable a building is. It has been recommended that a yardstickfor measuring environmental performance is needed [23]. 


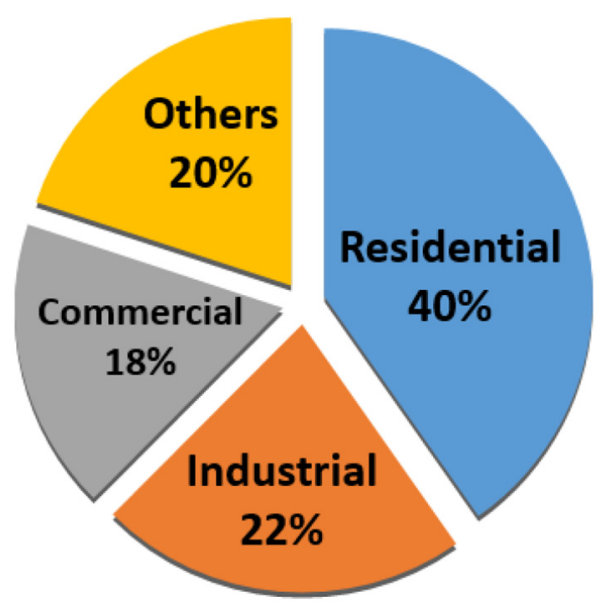

Fig. 5. Energy consumption sectors [14].

UAE and specifically the Emirate of Ajman are looking for innovative plans, citywide strategies, public outreach, and education campaigns to drive climate action and resilience. Masdar City is one of the most sustainable urban developments powered by renewable energy. The city is designed to [11]:

- Ensure a low carbon footprint throughout its construction and after;

- Renewable energy is the main power resource;

- Waste is reduced to as near to zero as possible by encouraging changes in behaviour and materials use and sorting;

- Capable of leading research and education into sustainable technology;

- Streets and buildings are designed to create comfortable environments while reducing air conditioning, heating, and artificial light;

- Educating three-quarters of the 40000 residents with $5 \mathrm{~h}$ of sustainability education each year;

- Leading research at its university ensures the city retains its sustainable identification and leading knowledge in sustainable living;

- Implementing full pedestrianisation within the city, with the transport network below ground.

Masdar City's objectives, such as living standards and work economically beneficial, reduce environmental damage. Pure renewable energy resources include solar thermal, photovoltaic, and wind. The other resources, such as geothermal and hydrogen energy sources, were later considered viable alternatives [24]. The Emirate of Ajman has been serving scientific research activities for the UAE and the whole world. It has been considered an example and used to encourage sustainable development efforts by the united nations. Projects and programs have been initiated by the Ajman Government and lead by Ajman Municipality and Planning Department (AMPA). Ajman Emirate has experienced right from the beginning the process of urbanisation journey in parallel to other Emirates and the rest of the world when the Government has always ensured that settlement undergoes a structured approach to eradicate urban poverty or informal housing in the city [25].

\subsection{Efforts towards green sustainable buildings in Ajman}

Residential buildings are responsible for $40 \%$ of energy consumption, Industrial $22 \%$, Commercial $18 \%$ and others $20 \%$ as shown in Figure 5 [14].

Ajman Government and with the efforts towards conversion to sustainable smart city issued a policy announced by the Municipality and Planning Department on, 31st of May, 2018, requiring all constructions to go green, effective on 1st of June [26], starting with villas and to have the rest of other types of buildings in a later date. Ajman Government was clear in their intention to convert the Emirate to the sustainable city as announced by Sheikh Rashid bin Humaid, the chairman of Ajman Municipality and Planning Department,who said: "The department is keen on implementing sustainability standards in all of the Emirate's vital sectors in order to establish for building the future of Ajman" [26]. Central Laboratory building was the first green building built following the global green building standards. It also falls in line with the Municipality's vision that seeks to find modern, sustainable ways to strengthen the infrastructure and build the future of Ajman, said the chairman of the Ajman Municipality and Planning [27]. The building's features are:

- Sunlight-reflecting glass providing insulation and electricity saving;

- Thermal bricks for energy-saving characteristics;

- Environment-friendly materials and green concrete.

\section{Achievements on public awareness}

The Ajman Municipality and Planning Department organised several activities to raise public awareness and transfer technology through conferences, seminars, training courses, and workshops. These activities aim to bring the exchange of ideas and valuable experience to contribute to current or future research on green practices, environmentally sound technologies, carbon footprint management, and support for expanding sustainable and environmentally friendly initiatives. During activities'sessions, practices carried out in the field of business and technology by experts and specialistsfrom many countries were presented and discussed. Scientific papers were published as an outcome of these activities focused on sustainability,comprehensive development and diversifiedenergy, legislation to preserve naturalresources and development methods amongstother topics. The Ajman International Environment Conference held every two years plus the Annual Ajman Environmental Seminar are good examples. These activities are lead and supported by the Ajman Government. Many related recommendations were put forward at the end of each event focused on many fields, such as [17]: 
Table 4. Strategic indicators for sustainable development in Ajman [17].

\begin{tabular}{|c|c|c|c|c|c|c|}
\hline Strategic indicators & General & 2016 & 2015 & 2018 & 2019 & 2020 \\
\hline Total green are in the emirate of Ajman & $\begin{array}{l}\text { Achieved } / \mathrm{m}^{2} \\
\text { Target } / \mathrm{m}^{2}\end{array}$ & $\begin{array}{lll}1 & 199 & 000 \\
1 & 190 & 559\end{array}$ & $\begin{array}{l}1620683 \\
1240000\end{array}$ & $\begin{array}{l}1751683 \\
1780000\end{array}$ & $\begin{array}{l}1799683 \\
1960000\end{array}$ & $\begin{array}{l}2034524 \\
2140000\end{array}$ \\
\hline Air Quality Index (WHO) & $\begin{array}{l}\text { Achieved } \% \\
\text { Target } \%\end{array}$ & $\begin{array}{l}81.4 \\
70\end{array}$ & $\begin{array}{l}76.12 \\
74\end{array}$ & $\begin{array}{l}89 \\
78\end{array}$ & $\begin{array}{l}92 \\
90\end{array}$ & $\begin{array}{l}94 \\
90\end{array}$ \\
\hline $\begin{array}{l}\text { Food Safety Index Safety Ratio } \\
\text { Of Botted Drinking Water }\end{array}$ & $\begin{array}{l}\text { Achieved } \% \\
\text { Target } \%\end{array}$ & $\begin{array}{l}89 \\
90\end{array}$ & $\begin{array}{l}90 \\
91\end{array}$ & $\begin{array}{l}90 \\
93.5\end{array}$ & $\begin{array}{l}96 \\
95.3\end{array}$ & $\begin{array}{l}96 \\
95.7\end{array}$ \\
\hline $\begin{array}{l}\text { Percentage of facilites compliance with laws } \\
\text { and legislations related to food safety }\end{array}$ & $\begin{array}{l}\text { Achieved } \% \\
\text { Target } \%\end{array}$ & & & & $\begin{array}{l}98.5 \\
80\end{array}$ & $\begin{array}{l}51.25 \\
80\end{array}$ \\
\hline $\begin{array}{l}\text { Percentage of food samples in compliance } \\
\text { with food safety regulations }\end{array}$ & $\begin{array}{l}\text { Achieved } \% \\
\text { Target } \%\end{array}$ & & & & $\begin{array}{l}94 \\
96\end{array}$ & $\begin{array}{l}97.5 \\
97\end{array}$ \\
\hline $\begin{array}{l}\text { Prevelence of major public health pests } \\
\text { (mice - flies - mosquitoes) }\end{array}$ & $\begin{array}{l}\text { Achieved } \% \\
\text { Target } \%\end{array}$ & & & & $\begin{array}{l}49.75 \\
45\end{array}$ & $\begin{array}{l}47 \\
36.75\end{array}$ \\
\hline Efective mangement of natural reserves (sectoral) & $\begin{array}{l}\text { Achieved } \% \\
\text { Target } \%\end{array}$ & & & $\begin{array}{l}56 \\
60\end{array}$ & & $\begin{array}{l}61 \\
65\end{array}$ \\
\hline OF liquid waste recycled & $\begin{array}{l}\text { Achieved } \% \\
\text { Target } \%\end{array}$ & & & $\begin{array}{l}99.99 \\
100\end{array}$ & $\begin{array}{l}99.99 \\
100\end{array}$ & $\begin{array}{l}99.99 \\
100\end{array}$ \\
\hline $\begin{array}{l}\text { Percentange of treated waste from the } \\
\text { total waste produced }\end{array}$ & $\begin{array}{l}\text { Achieved } \% \\
\text { Target } \%\end{array}$ & & & $\begin{array}{l}5.15 \\
10\end{array}$ & $\begin{array}{l}45.05 \\
50 \%\end{array}$ & $\begin{array}{l}50.51 \\
50 \%\end{array}$ \\
\hline Solid waste recycled & $\begin{array}{l}\text { Achieved } \% \\
\text { Target } \%\end{array}$ & & & $\begin{array}{l}4.2 \\
5\end{array}$ & $\begin{array}{l}4.9 \\
5\end{array}$ & $\begin{array}{l}3.9 \\
6\end{array}$ \\
\hline Percenta of treated medical waste & $\begin{array}{l}\text { Achieved } \% \\
\text { Target } \%\end{array}$ & & & $\begin{array}{l}100 \\
100\end{array}$ & $\begin{array}{l}100 \\
100\end{array}$ & $\begin{array}{l}100 \\
100\end{array}$ \\
\hline
\end{tabular}

- Symposiums shall be adopted to be permanently organised every year to serve the UAE sustainable development. Also, to keep up to date with the latest world achievements and results issued by the world international forums and all the latest technologies and research on renewable energy and green buildings in the UAE's interest;

- Accelerate the issuance of legislation to support renewable energy use in the Emirate for the new buildings and industrial facilities. The legislation supports environmentally friendly transport such as electric cars and hybrid cars and the latest inventions in this area to reduce carbon emissions and reduce the effects of global warming;

- Existing and new buildings should be set a minimum use of renewable energies by not less than $10 \%$ of what it is in reality;

- Identification and issuance of targets for saving energy consumed starts with rates not less than $10 \%$ and is reviewed every five years;

- Adopting green building regulations for new buildings and considering the possibility of improving the efficiency of existing buildings and supporting the issuance of special rules for the Emirate based on local and international regulations, taking into account the Emirate's specificity in this field;
- Experts in the forum to develop the green sustainable building policy's scientific foundations are prepared in the Emirate, recommending continuous contact with several experts to verify these policies' progress and quality;

- Develop plans and programs of education and awareness of renewable and new energy, including schools, universities and various community groups to raise environmental awareness and access to the highest grades in line with the targets and vision of wise leadership in the Emirate;

- Issuing decisions that stimulate and support industrial and commercial establishments to adopt renewable energy options and energy conservation methods and commit them to implement realistic objectives;

- To issue a comprehensive plan with the Emirate road map through which all the targets and implementation periods will be determined concerning the adoption of renewable energy and green buildings and implementation methods and ways to verify their success and continuously.

It was indicated by the International Renewable Energy Agency (IRENA), that doubling the share of renewables in the global energy mix would increase global GDP up to $1.1 \%$ by 2030 [28]. 
In response to the above initiatives, theAMPD has planned for strategies to usethe suitable renewable energy systemsin all building and industries in the Ajman city. Moreover, the buildings' regulations are to be introduced to support the national planning development Strategy, create a more sustainable urban environment, and extend the Kingdom's infrastructure's ability to meet future development needs [29].

\section{AMPD strategic indicators and achievements}

AMPD has carried out activities to implement its Sustainable strategic plans. Achievements are significantly shown in Table 4 with some selected indicators.

\section{Conclusions}

People started to live in urban areas all over the world increasingly. The UAE is one of the most attractive countries to many tourists and investors. This has put pressure and challenges on all Emirates and specifically the Emirate of Ajman to maintain safe, durable, and sustainable living that provide happiness and good standard wellbeing. Ajman Municipality and Planning Department (AMPD) is the authority that has played a significant role and was the organiser to put forward plans to overcome the associated environmental challenges. The principles and success parameters of the environmentally friendly city were presented and discussed in this article. It emphasised how these parameters are achieved and practised for the best of the Emirate of Ajman. AMPD has made full implementation to the United Nations Sustainable Development Goals (UNSDGs) and appointed each SDG to the related activity. These activities are SDGs associated with the AMPD strategies and goals, infrastructure and roads, waste management, community health \&well being and the climate change. It has been seen that practically understanding these goals leads to the high performance of implementation to the plans that helped achieve maintaining a smart, sustainable Ajman city. One of primarily achieved practices is the air-Quality related SDGs where the AMPD has the Municipality has installed Continuous Ambient Air Quality Monitoring Stations (CAAQMS) at various, air quality sensitive locations in the Emirate of Ajman. Moreover, a smart mobile vehicle that has been equipped with the latest artificial intelligence measuring systems. The Municipality has had plans to respond and put initiatives to climate change and practices for performing a sustainable energy performance and behaviours. Examples such as EcoFriendly Hybrid Vehicles which had an encouraging amount of energy savings and $\mathrm{CO} 2$ emissions. These vehicles are to be increased in numbers considering pure electric cars for the coming years. Another primarily achieved practice is waste management. AMPD has initiated sustainable waste management plans to achieve sustainable waste management, which has proven its effectiveness with many successful activities to target the goal of attaining no landfill. An example is the 'Day Without Plastic Bags' which was practised for several years. The article has reached concluding remarks for Ajman to achieve environmentally friendly smart city that the city is working intensively towards green sustainable buildings, ensuring a low carbon footprint throughout its construction and after. Besides, having a large percentage of its sustainable power supply by renewables with reduced waste is reduced to as near to zero as possible. AMPD has had a significant achievement to raise public awareness and transfer technology through conferences, seminars, training courses, and workshops. For this aspect, the article has reviewed the leading strategic indicators and recorded the achievement. The paper is to set all successful factors that should be considered when planning, implementing and evaluating regulations and polices to achieve the UNSDGs.

\section{References}

1. G. Haughton, C. Hunter, Sustainable cities (Routledge, 2004)

2. G. Ozkaya, C. Erdin, Evaluation of smart and sustainable cities through a hybrid MCDM approach based on ANP and TOPSIS technique, Heliyon 6, e05052-e05052 (2020)

3. A. D'Auria, M. Tregua, M. Vallejo-Martos, Modern conceptions of cities as smart and sustainable and their commonalities, Sustainability 10, 2642 (2018)

4. H. Bulkeley, M.M. Betsill, Rethinking sustainable cities: multilevel governanceand the "urban" politics of climate change, Environ. Pol. 14, 42e63 (2005)

5. J. Capdevila, M.I. Zarlenga, Smart city or smart citizens? The Barcelona Case, J. Strat. Manage 8, 266-282 (2015)

6. B. Cohen, Urbanisation in developing countries: current trends, future projectionsand key challenges for sustainability, Technol. Soc. 28, 63-80 (2006)

7. M. Hojer, S. Wangel, Smart sustainable cities: definition and challenges, in: L. Hilty, B. Aebischer (Eds.), ICT Innovations for Sustainability, Springere Verlag, Berlin, 2015, pp. 333349

8. J. Blewitt, Understanding Sustainable Development (Routledge, London, 2018)

9. A.S. Darwish, Green buildings to approach sustainable buildings by integrating wind and solar systems with smart technologies, in: A. Sayigh (Eds.), Green Buildings and Renewable Energy. Innovative Renewable Energy, Springer, Cham 2020

10. u.ae, Smart sustainable cities, 2020. https://u.ae/en/aboutthe-uae/digital-uae/smart-sustainable-cities (accessed January 21, 2021)

11. Bitesize. Sustainable living, 2021. https://www.bbc.co.uk/ bitesize/guides/zqvxdmn/revision/1 (accessed January 20, 2021)

12. AMPD, The First Sustainability Report, Ajman - UAE: Ajman Municipality and Planning Department, 2018

13. E. Mark, Application of SDGs to Air Pollution. The Atmospheric Pollution,Climate Change Nexus in Asia: Implications for a New Development Agenda, 2016. https://www.iges.or.jp/en/publication_documents/pub/ presentation/en/5343/S3.1.Mark_Elder.pdf 
14. A.S. Darwish, Renewable Energy Utilization - Aspects and Innovations: Sustainable, Green, and Smart Buildings in the Emirate of Ajman, 5th Ajman International Environment Conference, Ajman - UAE, 6-7 March 2018

15. J. Dartnell. Ajman launches eco-friendly hybrid vehicles. tahawultech, 2018. https://www.tahawultech.com/news/ ajman-eco-friendly-hybrid-vehicles/ (accessed January 23, 2021)

16. WAM, Rashid Al Nuaimi launches environment-friendly electric vehicle, 2017. https://www.emirates247.com/news/ emirates/rashid-al-nuaimi-launches-environment-friendlyelectric-vehicle-2017-03-05-1.649166 (accessed January 23, 2021)

17. AMPD, Ajman Municipality and Planning Department, (Official communications by authors, 2021)

18. A. Abdullah, Ajman observes' Day Without Plastic Bags', 2012. https://www.khaleejtimes.com/nation/general/ ajman-observes-daywithout-plastic-bags (accessed January 15, 2021)

19. AMPD, Ajman Municipality and Planning Department, (Official communications by authors, 2020)

20. EIS-ME, Mobile Artificial Intelligence Laboratory in Ajman, 2020. https://eis-me.com/mobile-artificial-intelligence-labo ratory-in-ajman/

21. T. Slaper, The triple bottom line: what is it and how does it work, 2011. https://www.ibrc.indiana.edu/ibr/2011/ spring/pdfs/article2.pdf (accessed January 21, 2021)
22. Darwish, Sustainable green smart buildings: future energy survivor, ISESCO J. Sci. Technol. 12, 35-42 (2017)

23. D. Crawley, I. Aho, Building environmental assessment methods: applications anddevelopment trends, Build. Res. Inf. 27, 300-308 (1999)

24. M. Premalatha, S.M. Tauseef, T. Abbasi, S.A. Abbasi, The promise and the performance of the world's first two zero carbon eco-cities, Renew. Sustain. Energy Rev. 25, 660-669 (2013)

25. J. Wahid, B. Saleh, M. Shihadeh, A. Arar, J. Awad, Urbanisation in Ajman pushing by housing development, Int. Trans. J. Eng. Manag. Appl. Sci. Technol., 1-11 (2019)

26. Rateitgreen, Green buildings becomes mandatory in Ajman, United Arab Emirates as of 1 June, 2018, 2018. https://www.rateitgreen.com/green-building-resources/sus tainable-building-news/green-buildings-becomes-mandatoryin-ajman-united-arab-emirates-as-of-june-1-2018/118 (accessed January 19, 2021)

27. A. Abdullah, Ajman's first green building is $40 \%$ done, 2019. https://www.khaleejtimes.com/nation/ajman/ajmans-firstgreen-building-40-done-1 (accessed January 20, 2021)

28. I. Msengi, R. Doe, T. Wilson, D. Fowler, C. Wigginton, S. Olorunyomi, I. Banks, R. Morel, Assessment of knowledge and awareness of "sustainability" initiatives among college students, Renew. Energy Environ. Sustain. 4, 6 (2019)

29. F. AlKubaisy, Greenery buildings Significance of courtyard houses design in the Arab world, Renew. Energy Environ. Sustain. 5, 5 (2020)

Cite this article as: Khaled Mueen Alhosani, Yaser Omar Kaied, Abdul Salam Kareem Darwish, Ajman an environmentally friendly city with its quality of life: review of sustainability challenges and achievements by Ajman Municipality and Planning Department, Renew. Energy Environ. Sustain. 6, 12 (2021) 